\title{
The Use of Antioxidants to Control Root Rot and Wilt Diseases of Pepper
}

\author{
Montaser Fawzy ABDEL-MONAIM ${ }^{1)}$, Mamdoh Ewis ISMAIL ${ }^{2)}$ \\ ${ }^{1)}$ Plant Pathology Research Institute, Agricultural Research Center, Giza, Egypt; ahmedismael91@yahoo.com \\ 2) Minia University, Department of Agriculture Plant Pathology,Egypt; fowzy_2008@yahoo.com (corresponding author)
}

\begin{abstract}
Ten isolates of Fusarium spp were isolated from pepper plants collected from different locations in New Valley Governorate, Egypt. Fusarium solani isolate FP2 and F. oxysporum isolate FP4 were highly pathogenic isolates but the other isolates moderate or less pathogenic to pepper plants (cv. Anaheim-M). The four antioxidant compounds (coumaric acid, citric acid, propylgalate and salicylic acid each at 100 and $200 \mathrm{ppm}$ ) were evaluated for their in vitro and in vivo agonist to Fusarium pathogenic isolates caused root rot and wilt diseases in pepper plants. All tested antioxidant compounds reduced damping-off, root rot/wilt and area under root rot/wilt progress curve when used as seed soaking, seedling soaking, and soil drench especially at $200 \mathrm{ppm}$ under greenhouse and field conditions compared with untreated plants. All chemicals increased fresh and dry weight of seedling grown in soil drenching or seed treatment with any antioxidants. At the same time, all tested chemicals significantly increase plant growth parameters i.e plant length, plant branching, and total yield per plant in case of seedling soaking or soil drench. In general, propylgalate at $200 \mathrm{ppm}$ was more efficient in reducing infection with damping-off, root rot and wilt diseases as well as increasing the seedling fresh weight, dry weight, plant length, plant branching, number of pod plant ${ }^{-1}$ and pod yield plant ${ }^{-1}$. On the other hand, all tested antioxidants had less or no effect on mycelial dry weight and mycelial leaner growth. On the contrary, all chemicals much reduced spore formation in both Fusarium species at 100 or 200 ppm and the inhibitory effect of antioxidants increased with increasing their concentrations.
\end{abstract}

Keywords: pepper, root diseases, antioxidants, soil borne fungi

\section{Introduction}

Sweet pepper (Capsicum annuum L.) belongs to the family solanaceae, which is an important group of vegetables cultivated extensively in Egypt and also widely cultivated in almost every country of the world. Pepper plants are liable to be attacked by several soil-borne pathogenic fungi which are responsible for considerable plant mortality and consequently high losses in the yield and quality in many parts of the world (Lu et al., 1984; Abada, 1994; Mushtaq and Hashmi, 1997).

Fusarium root rot and wilt are the most important diseases caused by Fusarium solani and $F$. oxysporum in sweet pepper plants. Fusarium root rot/wilt first appears as slight vein clearing on the outer portion of the younger leaves, followed by epinasty (downward drooping) of the older leaves. At the seedling stage, plants infected may wilt and die soon after symptoms appear. In older plants, vein clearing and leaf epinasty are often followed by stunting, yellowing of the lower leaves, formation of adventitious roots, wilting of leaves and young stems, defoliation, marginal necrosis of remaining leaves, and finally death of the entire plant. Browning of the vascular tissue is a strong evidence of Fusarium wilt in sweet pepper (Agrios, 1988).

Because of hazards of pesticides in general, and fungicides in specific, on public health and environmental balance (Elad, 1992) a relatively recent direction of pest control management was introduced. Inducing or acquiring the systemic resistance in the host plant became a good target for minimizing disease incidence or severity with least cost and without environmental pollution.

Antioxidants which save to human and environment had been used successfully to control some plant diseases such as root and pod rot in peanut (Elwakil, 2003), Fusarium wilt in chickpea (Nighat-Sarwar et al., 2005), faba bean chocolate spot (Hassan et al., 2006 ), peanut root rot (Mahmoud et al., 2006), Fusarium wilt in tomato (ElKhallal, 2007a; Mohamed et al., 2007), root rot and leaf blight in lupine (Abdel-Monaim, 2008), damping- off in pepper (Rajkumar, 2008).

At the same time, Mostasa (2006) reported that application of antioxidants, e.g. ascorbic, salicylic, coumaric, benzoic acids and propylgalate as either seed soaking or soil drenching proved sufficient protection against cumin caused by Fusarium oxysporum, F. sp. cumini or Acreromonium egyptiacum.

The present study aims to evaluate antioxidant compounds i.e coumaric, salicylic, citric acids and propylgalate as chemical inducers on pepper plants against root rot and wilt diseases, effect on growth parameters and pod yield and their effect on dry weight, leaner growth and sporulation in vitro, of Fusarium solani and F. oxysporum. 


\section{Materials and methods}

\section{Isolation and identification of the causal organisms}

Samples of pepper plants showing root rot and wilt disease symptoms were collected from different locations of New Valley Governorate (Kharga, Dakhla, Farfrah and Baris Oozes). All samples were subjected to isolation trials for the organisms according to the method devised by Sahi and Khalid (2007). The purified isolated fungi were identified according to cultural and microscopically characters described by Gilman (1957), Barnett and Hunter (1972) and Nelson et al. (1983).

\section{Pathogenicity test}

Ten isolates of Fusarium spp were selected to study their pathogenic ability to induce root rot and wilt on pepper seedling ( $40 \mathrm{~d}$-old) in pots. Plastic pots $(30 \mathrm{~cm}$ in diameter) containing sterilized sand loam soil infested individually with inoculums of each fungus, was grown on barley-sandy medium (140 g barley grains, $60 \mathrm{~g}$ sand and $60 \mathrm{ml}$ water) for two weeks at $25 \pm 1^{\circ} \mathrm{C}$. Five pots were used for each fungus. Check treatment (control) was prepared without the addition of the tested fungi. Healthy seedlings of pepper (cv. 'Anaheim-M') were sown at the rate of 5 seedlings/pot. The pots were kept under careful observation in the open field of plant pathology Dept., New Valley Agric. Eight weeks after sowing rot and wilt were examined. Re-isolation was carried out from some of the artificially diseased plants to fulfill Koch's postulations and the developed fungi were confirmed with the original isolates.

\section{Disease assessment}

60 days from planting, pepper plants were removed from the soil, washed thoroughly to remove soil debris, root rot/wilt assessment as follows:

$0=$ neither root discoloration nor leaf yellowing, $1=$ $1-25 \%$ root discoloration or one leaf yellowed, $2=26-50 \%$ root discoloration or more than one leaf yellowed, $3=51$ $75 \%$ root discoloration or vascular discoloration plus one leaf wilted, $4=$ up to $76 \%$ root discoloration or more than one leaf wilted and $5=$ completely dead plants. For each replicate a disease severity index (DSI) similar to the one described by Liu et al., (1995) was calculated as follows:

\section{$\mathrm{DSI}=\sum \mathrm{d} /\left(\mathrm{d}_{\max } \mathrm{Xn}\right) \mathrm{X} 100$}

Whereas: $d$ is the disease rating of each plant, $d$ max is the maximum disease rating and $\mathrm{n}$ is the total number of plants examined in each replicate.

\section{Effect of antioxidant compounds on disease severity under greenhouse conditions}

Coumaric acid (COA), citric (CA), salicylic acid (SA) and propylgalate $(\mathrm{PG})$ were tested for controlling pepper root rot and wilt diseases caused by Fusarium solani and F. oxysporum at two concentrations (100 and $200 \mathrm{ppm}$ ) in pot experiments. These compounds applied by different methods as follows.

\section{Seed socking}

Healthy pepper seeds were soaked in the tested solutions for $12 \mathrm{hr}$. (600 seeds per $100 \mathrm{ml}$ test solution), then 5 seeds were sowed in each pot ( $25 \mathrm{~cm}$ in diameters), five pots were used for each test as replicates. Percentage of damping-off and root rot/wilt severity were recorded 4 and 8 weeks after planting, respectively. At the end of the experiment, fresh and dry weight per plant was recorded.

\section{Seedling socking}

Healthy pepper seedlings ( 40 days old) were soaked in tested solution for $12 \mathrm{hr}$. (100 seedlings per $100 \mathrm{ml}$ ), then 5 seedlings were sowed in each pot, five pots used each test as replicates. Disease severity recorded each 10 interval days for 60 days. The mean of area under root rot/wilt progress curve (AUR/WPC) for each replicate was calculated by the formula suggested by Pandy et al. (1989) and calculated as follows:

AUR/WPC $=\mathrm{D}\left[1 / 2\left(\mathrm{Y}_{1}+\mathrm{Y}_{\mathrm{k}}\right)+\left(\mathrm{Y}_{2}+\mathrm{Y}_{3}+\ldots .+\mathrm{Y}_{\mathrm{k}-1}\right)\right]$ Where $\mathrm{D}=$ Time interval; $\mathrm{Y}_{1}=$ First disease severity; $\mathrm{Y}_{\mathrm{k}}=$ Last disease severity; $Y_{2}, Y_{3}, \ldots Y_{k-1}=$ Intermediate disease severity.

\section{Soildrenching}

Non treated seedlings and/or seeds were sowed in pots (five per pot). Pots were irrigated with COA, CA, SA and PG solutions at two concentrations (100, $200 \mathrm{ppm}$ ) when they were planted. Irrigation with the test solution was applied at rate $50 \mathrm{ml}$ test solution per pot. Five pots were used for each test as replicates. Damping-off, root rot/wilt and AUR/WPC were recorded as mentioned before.

All experiments grow in infested soil with Fusarium solani (isolate PF2) and/ or F. oxysporum (isolate PF4) at $3 \%$ of inocula prepared as before.

\section{Effect of antioxidants on growth and sporulation of the tested fungi in vitro}

Coumaric, citric, salicylic acids and propylgalate were used separately at 100 and $200 \mathrm{ppm}$ for studying their effect on dry weight, leaner growth and sporulation of the tested fungi:

Mycelium disks ( $7 \mathrm{~mm}$ diameter) from the growing edge of 7-day-old cultures of each Fusarium solani and $F$. oxysporum were inoculated onto these plates containing $10 \mathrm{~mm}$ sterilized Czpecks solid medium amended with each concentration of each antioxidant compounds in order to test the effect of the chemicals on linear growth. In addition, sporulation estimated after 7 days incubation under the same conditions using a heamocytometer with the help of a light microscope (Tzeng and DeVay, 1989). At the same time flask $250 \mathrm{ml}$ containing $50 \mathrm{ml}$ Czpeck's medium were prepared and amended with each concentration of each antioxidant compounds. Antioxidant free 
48

medium was served as control. Three replicates were used for each treatment.

The effect of antioxidant compounds on diseases severity, plant vigour and yield under field conditions

This experimental, factorial block design experiment was conducted at sowing date of 15 February of two successive growing seasons 2008-2009 in a field naturally infected with the causal organisms of root rot and wilt diseases of pepper located at the experimental farm of Kharga Agric. Station, New Valley Governorate. The main plots were antioxidant tested, sub plots were concentrations, sub sub plots were seedlings soaking and/or soil drenching. Seedlings were sacked at rate 100 transplanting per $100 \mathrm{ml}$ for $12 \mathrm{hr}$. while in case of soil drenching, tested antioxidants were applied at rate $25 \mathrm{ml}$ per hill when planting. The field plots $\left(9 \mathrm{~m}^{2}\right)$ consisted of 3 rows of $3 \mathrm{~m}$ long and $1 \mathrm{~m}$ in between. One seedlings/hill was sown with 50 $\mathrm{cm}$ apart between hills. Untreated seedlings were grown in untreated soil used as control. Disease severity were recorded as above each 30 days for 4 months. At the end of the growing season, the plant height and the number of branches were calculated. At the same time, during the experiment, pods per plant were collated and calculated on number per plant and weight of pods per plant.

In all experiments the least significant difference (LSD) at 0.05 confidences was determined according to Gomez and Gomez (1984).

\section{Results}

Pathogeenicity tests indicated that these isolates significantly varied in the root rot/wilt severity detected in pepper plants cv. Anaheim-M (Tab. 1). The highest of disease severity of infected pepper was produced by PF4 (87\%) followed by PF2 (82\%), while isolates FP7 and FP9 were the weak ones. Identification procedures of the isolated fungi proved the presence of 3 Fusarium solani isolates (PF1 to PF3) and 7 isolates of Fusarium oxysporum (PF4 to PF10).

\section{The effect of antioxidants on pepper disease severity under greenhouse conditions:}

In order to study, the role of the antioxidants on pathogenic process a determination procedure was carried out using one isolate each of Fusarium solani (isolate PF2) and F. oxysporum (isolate PF4). These compounds were applied with three methods i.e seed soaking, transplanting soaking and soil drenching.

\section{The effect of seed soaking}

Soaking pepper seeds in antioxidant solutions before planting resulted in the increase of resistance pepper seedlings and old plants against to infection with the tested fungi (Tab. 2). The resistance of pepper was enhanced by increasing antioxidant concentration. Propylgalate was the
Tab. 1. Pathogenicity tests of fungal isolates obtained from naturally diseased paper roots growing in different location at New Valley Governorate, Egypt

\begin{tabular}{cccc}
\hline Isolates & Location & $\begin{array}{c}\text { Disease } \\
\text { index }\end{array}$ & $\begin{array}{c}\text { Disease } \\
\text { severity }\end{array}$ \\
\hline FP1 & Kharga & 3.60 & 72 \\
FP2 & Kharga & 4.10 & 82 \\
FP3 & Baris & 2.05 & 41 \\
FP4 & Dakhla & 4.35 & 87 \\
FP5 & Dakhla & 1.30 & 26 \\
FP6 & Baris & 2.25 & 45 \\
FP7 & Farfrah & 0.40 & 8 \\
FP8 & Farfrah & 1.35 & 27 \\
FP9 & Kharga & 0.80 & 16 \\
FP10 & Dakhla & 1.45 & 29 \\
& & 2.17 & 43.3 \\
\hline
\end{tabular}

most effective antioxidant as they greatly retarded damping. Soaking of pepper seeds in the chemical solution (200 $\mathrm{ppm}$ ) of propylgalate for $12 \mathrm{hr}$. before planting reduced damping-off caused by $F$. solani and $F$. oxysporum. The infection was from 45.6 and $38.4 \%$ in control to 6.3 and $6.4 \%$. Root rot/wilt severity was reduced from 27.4 and $46.4 \%$ in control to 4.4 and $9.0 \%$.

On the other hand, pepper seeds soaking in antioxidants increase fresh and dry weight compared to untreated plants under infection with Fusarium solani and/ or $F$. oxysporum. Fresh weight and dry weight increase by increasing of antioxidant concentration. Seeds treated with propylgalate at 100 or $200 \mathrm{ppm}$ resulted in higher fresh and dry weight compared to any of the other samples which underwent treatment. The weight per fresh plant was 4.900 and $4.215 \mathrm{~g} \mathrm{plant}^{-1}$ in case of seed treated with propylgalate at $200 \mathrm{ppm}$ we can compare the values to 1.488 and $1.354 \mathrm{gm} /$ plant in control when growing in infested soil with $F$. solani and $F$. oxysporum individually respectively. Dry weight was 1.275 and $1.205 \mathrm{gm} /$ plant compared to 0.256 and $0.241 \mathrm{gm} /$ plant in control.

\section{Soil drenching}

Drenching soil with antioxidant solutions resulted in an increase pepper resistance against infection with the tested fungi (Tab. 3 and 4). Data in (Tab. 3) indicate that all antioxidants reduce damping-off, root rot/wilt caused by Fusarium solani and F. oxysporum and increase of fresh and dry weight per plant compared with control.

Propylgalate at $200 \mathrm{ppm}$ was more effective than the other antioxidants to suppress pepper damping-off and root rot/wilt. The percentage of damping-off was 4.2 and $6.0 \%$ in case of soil drenching with propylgalate compared to 45.6 and $38.4 \%$ under control. As for this compound it reduces root rot/wilt severity from 27.4 and $46.4 \%$ to 3.6 and $8.2 \%$. 
Tab. 2. Effect of pepper seed soaking in antioxidant solutions on damping- off and root rot/wilt caused by Fusarium solani isolate FP2 and Fusarium oxysporum isolate FP4 in pots

\begin{tabular}{|c|c|c|c|c|c|c|c|c|c|}
\hline \multirow[b]{2}{*}{ Treatments } & \multirow[b]{2}{*}{$\begin{array}{l}\text { Con. } \\
\text { (ppm) }\end{array}$} & \multicolumn{4}{|c|}{ Fusarium solani FP2 } & \multicolumn{4}{|c|}{ Fusarium oxysporum FP4 } \\
\hline & & $\begin{array}{c}\% \\
\text { Damping- } \\
\text { off }\end{array}$ & $\begin{array}{c}\% \\
\text { Root rot/ } \\
\text { Wilt }\end{array}$ & $\begin{array}{c}\text { Fresh } \\
\text { weight/ } \\
\text { plant }(\mathrm{gm})\end{array}$ & $\begin{array}{c}\text { Dry } \\
\text { weight/ } \\
\text { plant (gm) }\end{array}$ & $\begin{array}{c}\% \\
\text { Damping- } \\
\text { off }\end{array}$ & $\begin{array}{c}\% \\
\text { Root rot/ } \\
\text { Wilt }\end{array}$ & $\begin{array}{c}\text { Fresh } \\
\text { weight/ } \\
\text { plant }(\mathrm{gm})\end{array}$ & $\begin{array}{c}\text { Dry } \\
\text { weight/ } \\
\text { plant }(\mathrm{gm})\end{array}$ \\
\hline \multirow{3}{*}{$\begin{array}{c}\text { Coumaric } \\
\text { acid }\end{array}$} & 100 & $15.0^{\mathrm{a}}$ & 13.3 & 3.377 & 0.932 & 18.2 & 20.0 & 1.686 & 0.509 \\
\hline & 200 & 11.2 & 8.8 & 3.581 & 1.061 & 11.1 & 13.5 & 2.525 & 0.892 \\
\hline & Mean & 13.1 & 11.05 & 3.479 & 0.997 & 14.65 & 16.75 & 2.106 & 0.701 \\
\hline \multirow{3}{*}{ Citric acid } & 100 & 30.0 & 16.2 & 3.248 & 0.906 & 25.1 & 19.2 & 1.682 & 0.401 \\
\hline & 200 & 18.0 & 14.1 & 3.542 & 0.937 & 20.0 & 16.0 & 2.498 & 0.733 \\
\hline & Mean & 24.0 & 15.15 & 3.395 & 0.922 & 22.55 & 17.6 & 2.090 & 0.567 \\
\hline \multirow{3}{*}{ Propylgalate } & 100 & 10.0 & 6.0 & 4.615 & 1.113 & 8.3 & 13.2 & 2.666 & 0.625 \\
\hline & 200 & 6.3 & 4.4 & 4.900 & 1.275 & 6.4 & 9.0 & 4.215 & 1.205 \\
\hline & Mean & 8.15 & 5.2 & 4.7575 & 1.194 & 7.35 & 11.1 & 3.441 & 0.915 \\
\hline \multirow{3}{*}{ Salicylic acid } & 100 & 25.0 & 11.0 & 2.921 & 1.103 & 20.4 & 23.5 & 2.215 & 0.808 \\
\hline & 200 & 15.3 & 9.5 & 3.144 & 1.198 & 13.1 & 14.0 & 2.619 & 0.969 \\
\hline & Mean & 20.15 & 10.25 & 3.033 & 1.151 & 16.75 & 18.75 & 2.417 & 0.889 \\
\hline \multicolumn{2}{|c|}{ Control } & 17.73 & 27.4 & 1.488 & 0.256 & 38.4 & 46.4 & 1.354 & 0.241 \\
\hline
\end{tabular}

\begin{tabular}{lllll}
\hline LSD at 0.05 for: & Damping-off & Root rot/Wilt & Fresh weight/plant & Dry weight/plant \\
\hline Treatments $(\mathrm{A})=$ & 3.522 & 0.436 & 0.291 & 0.080 \\
Concentrations $(\mathrm{B})=$ & $* *$ & $* *$ & ${ }^{* *}$ & ${ }^{* *}$ \\
Isolates $(\mathrm{C})=$ & ${ }^{* *}$ & ${ }^{* *}$ & ${ }^{* *}$ & ${ }^{* *}$ \\
Interactions $(\mathrm{AxBxC})=$ & 5.636 & $\mathrm{~ns}$ & $\mathrm{~ns}$ & 0.140 \\
\hline
\end{tabular}

aValues are means of 3 replicates

Tab. 3. Effect of soil drenching with antioxidant solutions on damping- off and root rot/wilt caused by Fusarium solani isolate FP2 and $F$. oxysporum isolate $\mathrm{FP} 4$ in pots

\begin{tabular}{|c|c|c|c|c|c|c|c|c|c|}
\hline \multirow[b]{2}{*}{ Treatments } & \multirow[b]{2}{*}{$\begin{array}{l}\text { Con. } \\
\text { (ppm) }\end{array}$} & \multicolumn{4}{|c|}{ Fusarium solani isolate FP2 } & \multicolumn{4}{|c|}{ Fusarium oxysporum isolate FP4 } \\
\hline & & $\begin{array}{c}\% \\
\begin{array}{c}\text { Damping- } \\
\text { off }\end{array} \\
\end{array}$ & $\begin{array}{c}\% \\
\text { Root rot/ } \\
\text { Wilt }\end{array}$ & $\begin{array}{c}\text { Fresh } \\
\text { weight/ } \\
\text { plant }(\mathrm{gm})\end{array}$ & $\begin{array}{c}\text { Dry } \\
\text { weight/ } \\
\text { plant }(\mathrm{gm})\end{array}$ & $\begin{array}{c}\% \\
\text { Damping- } \\
\text { off }\end{array}$ & $\begin{array}{c}\% \\
\text { Root rot/ } \\
\text { Wilt }\end{array}$ & $\begin{array}{c}\text { Fresh } \\
\text { weight/ } \\
\text { plant (gm) }\end{array}$ & $\begin{array}{c}\text { Dry } \\
\text { weight/ } \\
\text { plant }(\mathrm{gm})\end{array}$ \\
\hline \multirow{3}{*}{ Coumaric acid } & 100 & $12.4^{a}$ & 10.3 & 4.141 & 1.325 & 15.1 & 16.0 & 2.961 & 0.619 \\
\hline & 200 & 8.4 & 7.2 & 4.861 & 1.610 & 9.3 & 10.2 & 2.910 & 0.993 \\
\hline & Mean & 10.4 & 8.75 & 4.501 & 1.468 & 12.2 & 13.1 & 2.936 & 0.806 \\
\hline \multirow{3}{*}{ Citric acid } & 100 & 25.1 & 12.4 & 3.806 & 1.205 & 23.2 & 16.4 & 1.961 & 0.631 \\
\hline & 200 & 15.4 & 10.4 & 3.963 & 1.310 & 16.2 & 12.1 & 2.631 & 0.803 \\
\hline & Mean & 20.25 & 11.4 & 3.885 & 1.258 & 19.7 & 14.25 & 2.296 & 0.717 \\
\hline \multirow{3}{*}{ Propylgalate } & 100 & 8.0 & 5.1 & 4.810 & 1.351 & 6.1 & 10.4 & 3.061 & 0.811 \\
\hline & 200 & 4.2 & 3.6 & 5.201 & 1.462 & 6.0 & 8.2 & 5.010 & 1.905 \\
\hline & Mean & 6.1 & 4.35 & 5.006 & 1.407 & 6.05 & 9.3 & 4.036 & 1.358 \\
\hline \multirow{3}{*}{ Salicylic acid } & 100 & 26.4 & 13.5 & 3.410 & 1.061 & 14.6 & 20.1 & 2.41 & 0.905 \\
\hline & 200 & 13.1 & 8.1 & 3.610 & 1.135 & 10.4 & 12.3 & 3.162 & 1.108 \\
\hline & Mean & 19.75 & 10.8 & 3.510 & 1.098 & 12.5 & 16.2 & 2.786 & 1.007 \\
\hline \multirow[t]{6}{*}{ Control } & & 45.6 & 27.4 & 1.488 & 0.256 & 38.4 & 46.4 & 1.354 & 0.241 \\
\hline & LSD & 0.05 for: & Damping-off & Root rot/Wilt & Fresh v & eight/plant & Dry weight/plant & & \\
\hline & Trea & ents $(\mathrm{A})=$ & 1.031 & 0.370 & 0.149 & & 0.620 & & \\
\hline & Con & ntrations $(\mathrm{B})=$ & ** & ** & ** & & ** & & \\
\hline & Isola & $s(C)=$ & ** & ** & ** & & ** & & \\
\hline & Inter & tions $(\mathrm{AxBxC})=$ & 3.634 & 2.732 & 0.280 & & 0.123 & & \\
\hline
\end{tabular}


Tab. 4. Effect of soil drenching with antioxidant solutions on area under root rot/wilt progress curve caused by Fusarium solani isolate FP2 and Fusarium oxysporum isolate FP4 in pots

\begin{tabular}{cccccc}
\hline \multirow{2}{*}{ Treatments } & Con. & \multicolumn{4}{c}{ Area under root rot/wilt progress carve caused by } \\
\cline { 3 - 6 } & $(\mathrm{ppm})$ & Fusarium solani isolate FP2 & Fusarium oxysporum isolate FP4 \\
\cline { 3 - 6 } & & AURR/WPC & \% Protection & AURR/WPC & \% Protection \\
\hline \multirow{3}{*}{ Coumaric acid } & 100 & $440.4^{\mathrm{a}}$ & 54.13 & 483.3 & 54.09 \\
& 200 & 243.9 & 74.59 & 248.4 & 76.40 \\
\hline \multirow{3}{*}{ Citric acid } & Mean & 342.15 & 64.36 & 365.85 & 65.25 \\
& 100 & 459.5 & 52.14 & 612.0 & 41.86 \\
\hline \multirow{3}{*}{ Propylgalate } & 200 & 348.7 & 63.68 & 399.7 & 62.03 \\
& Mean & 404.1 & 57.91 & 505.85 & 51.95 \\
\hline \multirow{3}{*}{ Salicylic acid } & 100 & 320.9 & 66.57 & 327.3 & 68.91 \\
& 200 & 192.0 & 80.00 & 180.0 & 82.901 \\
\hline & Mean & 256.45 & 73.29 & 253.65 & 75.901 \\
\hline
\end{tabular}

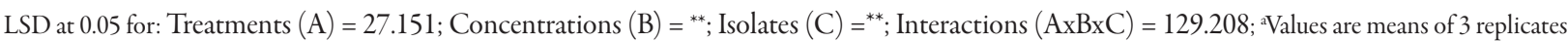

The fresh and dry weight were increased from 1.488 , $1.354 \mathrm{~g} \mathrm{FW}$ plant ${ }^{-1}$ in control to $5.201,5.01 \mathrm{~g} \mathrm{plant}^{-1}$ and $0.256,0.241 \mathrm{~g} \mathrm{DW}$ plant $^{-1}$ in control to $1.462,1.505 \mathrm{~g}$ DW plant ${ }^{-1}$ in PG treatment.

On the other hand, soil drenching with antioxidants protect of pepper seedling against infection with tested fungi (Tab. 4). The effect of antioxidants was enhanced by increasing antioxidant concentration. Using Propylgalate solution at $200 \mathrm{ppm}$ proved to reduce the area under root rot/wilt progress curve (AURR/PC) caused by $F$. solani and $F$. oxysporum (80, $82.91 \%$ protection), followed by coumaric acid at $200 \mathrm{ppm}$ (74.95 and $76.40 \%$ protection). Soil drenching with citric acid at $100 \mathrm{ppm}$ was less effective ( 52.14 and $41.86 \%$ protection).

\section{Seedling soaking}

Pepper seedling (40 day-old) soaking in antioxidant solutions reduced AURR/WPC caused by $F$. solani and F. oxysporum compared to untreated seedling (Tab. 5). Increasing antioxidant concentration enhanced pepper resistance. The lowest area under root rot/wilt progress carve was provided by PG at $200 \mathrm{ppm}$ (212.1 and 207.3 PG treatment at $200 \mathrm{ppm}$ in case of $F$. solani and $F$. oxysporum, rrespectively compared with 960 and 1052.7 in control.) $4.215 \mathrm{~g} \mathrm{plant}^{-1}$ in case of seed treated with propylgalate at $200 \mathrm{ppm}$ compared with 1.488 and $1.354 \mathrm{~g} \mathrm{plant}^{-1}$ in control when growing in infested soil with $F$. solani and $F$. oxysporum individually respectively. Also, dry weight was 1.275 and 1.205 g plant $^{-1}$ compared with 0.256 and 0.241 $\mathrm{g}$ plant $^{-1}$ in control.Generally, seed seedling and/or soil drenching with propylgalate increased of the resistance to infection with tested and gave highly fresh and dry weight of pepper seedlings.
The effect of tested antioxidants on the fungal growth:

The effect of the tested antioxidants on linear growth, dry weight and spore formation of the isolated fungi was carried out. Data in (Tab. 6) show that all the tested antioxidants have little effect on linear growth and dry weight of both fungal isolates. On the other hand, all tested antioxidants greatly inhibit the spore formation at the two tested concentrations (100 and $200 \mathrm{ppm}$ ). The effect of chemicals increase by increasing the concentration. Propylgalate was the highest inhibitory effect on spore formation for both tested fungal isolates (15.60 and $21.7 \times 10^{5}$ compared with 83.0 and $68.4 \times 10^{5}$ in control).

\section{Effect of antioxidants on pepper disease severity under} field conditions:

Under field conditions, the tested antioxidants were applied with seedling soaking and/or soil drenching.

\section{Soil drenching}

Significant variants between antioxidants were tested for controlling pepper root rot/wilt diseases in both seasons under field conditions (Tab. 7). Every antioxidants used was significantly reduced on the area under root rot / wilt progress curve. Propylgalate was the highest efficient in reducing AURR/WPC followed by salicylic acid especially at higher tested concentration (200 ppm). The protection of pepper plant were 75.79 and $76.19 \%$ in both seasons, respectively when soil was drenched with propylgalate at $200 \mathrm{ppm}$. On the other hand, soil drenching with citric acid recorded the lowest protection against root rot/ wilt (35.60 and $33.56 \%$ protection at $100 \mathrm{ppm}$ in both seasons, respectively). 
Tab. 5. Effect of paper seedling soaking in antioxidant solutions on area under root rot/wilt progress curve caused by Fusarium solani isolate FP2 and Fusarium oxysporum isolate FP4 in pots

\begin{tabular}{|c|c|c|c|c|c|}
\hline \multirow{3}{*}{ Treatments } & \multirow{3}{*}{$\begin{array}{l}\text { Con. } \\
\text { (ppm) }\end{array}$} & \multicolumn{4}{|c|}{ Area under root rot/wilt progress carve caused by } \\
\hline & & \multicolumn{2}{|c|}{ Fusarium solani FP2 } & \multicolumn{2}{|c|}{ Fusarium oxysporum FP4 } \\
\hline & & AURR/WPC & $\%$ Protection & AURR/WPC & $\%$ Protection \\
\hline \multirow{3}{*}{ Coumaric acid } & 100 & $624.0^{\mathrm{a}}$ & 35.00 & 627.2 & 40.42 \\
\hline & 200 & 368.1 & 61.66 & 392.8 & 62.69 \\
\hline & Mean & 496.05 & 48.33 & 510.0 & 51.55 \\
\hline \multirow{3}{*}{ Citric acid } & 100 & 740.0 & 22.92 & 744.0 & 29.32 \\
\hline & 200 & 608.1 & 36.66 & 488.0 & 53.64 \\
\hline & Mean & 674.05 & 29.79 & 616.0 & 41.48 \\
\hline \multirow{3}{*}{ Propylgalate } & 100 & 392.6 & 59.10 & 567.6 & 46.08 \\
\hline & 200 & 212.1 & 77.91 & 207.3 & 80.31 \\
\hline & Mean & 302.35 & 68.52 & 387.45 & 63.19 \\
\hline \multirow{3}{*}{ Salicylic acid } & 100 & 728.2 & 24.15 & 711.0 & 32.46 \\
\hline & 200 & 404.6 & 57.85 & 327.3 & 68.91 \\
\hline & Mean & 566.4 & 41.00 & 519.15 & 50.68 \\
\hline \multicolumn{2}{|c|}{ Control } & 960.0 & - & 1052.7 & - \\
\hline
\end{tabular}

LSD at 0.05 for: Treatments $(A)=29.250$; Concentrations $(B)={ }^{* *}$; Isolates $(C)={ }^{* *} ;$ Interactions $(A x B x C)=120.451^{2}$ Values are means of 3 replicates

\section{Seedling soaking}

Data in (Tab. 8) show that all the tested antioxidants significantly reduced the area under disease progress curver compared to control treatment. The effect of antioxidant increased by increasing in concentration In this respect propylgalate was the highest efficient in reducing AURR/ WPC compared to the other antioxidants. The AURR/ WPC was recorded 315.4 and 345.2 in case of PG at 200 compared to 1450.60 and 1545.50 in control in both seasons, respectively. Seedling soaked in SA came next PG where it decreased of AURR/WPC from 1450.6 and 1545.50 in control to 399.2 and 355.2 in SA treatment in both seasons, respectively. Pepper seedling sacking in citric acid was recorded as the lowest protection to root rot/ wilt diseases in both seasons, it was recorded by 835.0 and 615.4 at 100 and 200 ppm in season 2007-2008 compared

Tab. 6. Effect of antioxidant compounds on dry weight, linear growth and spore formation of Fusarium solani isolate FP2 and Fusarium oxysporum isolate FP4 grown on Czapek's medium

\begin{tabular}{|c|c|c|c|c|c|c|c|c|c|c|}
\hline \multirow{2}{*}{ Treatments } & \multirow{2}{*}{$\begin{array}{l}\text { Con. } \\
\text { (ppm) }\end{array}$} & \multicolumn{3}{|c|}{ Dry weight (mg/ $50 \mathrm{ml}$ medium) } & \multicolumn{3}{|c|}{ Linear growth $(\mathrm{mm})$} & \multicolumn{3}{|c|}{ Sporulation $\mathrm{X} 10^{5} / \mathrm{cm}^{2}$} \\
\hline & & FP2 & $\mathrm{FP} 4$ & Mean & $\mathrm{FP} 2$ & FP4 & Mean & FP2 & FP4 & Mean \\
\hline \multirow{3}{*}{ Coumaric acid } & 100 & $397.7^{\mathrm{a}}$ & 374.0 & 385.85 & 86.3 & 88.0 & 87.15 & 29.6 & 34.3 & 31.95 \\
\hline & 200 & 381.0 & 363.3 & 372.15 & 83.6 & 88.3 & 85.95 & 18.6 & 29.5 & 24.05 \\
\hline & Mean & 389.35 & 368.65 & 379.0 & 84.95 & 88.15 & 86.55 & 24.1 & 31.9 & 28.00 \\
\hline \multirow{3}{*}{ Citric acid } & 100 & 410.0 & 337.1 & 373.55 & 89.3 & 87.7 & 88.5 & 30.4 & 47.9 & 39.15 \\
\hline & 200 & 388.0 & 328.4 & 358.2 & 85.7 & 87.8 & 86.75 & 29.8 & 35.6 & 32.70 \\
\hline & Mean & 399.0 & 332.75 & 365.86 & 87.5 & 87.75 & 87.63 & 30.1 & 41.75 & 35.93 \\
\hline \multirow{3}{*}{ Propylgalate } & 100 & 386.3 & 374.3 & 380.3 & 82.8 & 81.6 & 82.2 & 18.5 & 22.0 & 20.25 \\
\hline & 200 & 364.0 & 353.8 & 358.9 & 80.0 & 82.0 & 81.0 & 15.6 & 21.7 & 18.65 \\
\hline & Mean & 375.15 & 364.05 & 369.6 & 81.4 & 81.8 & 81.6 & 17.05 & 21.85 & 19.45 \\
\hline \multirow{3}{*}{ Salicylic acid } & 100 & 404.7 & 353.6 & 379.15 & 88.2 & 86.7 & 87.45 & 37.8 & 33.6 & 35.70 \\
\hline & 200 & 405.8 & 347.2 & 376.5 & 86.7 & 87.3 & 87.0 & 32.8 & 23.3 & 28.05 \\
\hline & Mean & 405.25 & 350.4 & 755.65 & 87.45 & 87.0 & 87.23 & 35.3 & 28.45 & 31.86 \\
\hline Control & & 408.4 & 373.6 & 391.0 & 90.0 & 90.0 & 90.0 & 83.0 & 68.4 & 75.70 \\
\hline
\end{tabular}

\begin{tabular}{llll}
\hline LSD at 0.05 for: & Dry weight & Linear growth & Sporulation \\
\hline Treatments $(\mathrm{A})=$ & 5.431 & 3.069 & 1.768 \\
Concentrations $(\mathrm{B})=$ & ${ }^{* *}$ & ${ }^{* *}$ & ${ }^{* *}$ \\
Isolates $(\mathrm{C})=$ & ${ }^{* *}$ & $\mathrm{~ns}$ & ${ }^{* *}$ \\
Interactions $(\mathrm{AxBxC})=$ & 11.736 & $\mathrm{~ns}$ & 5.076 \\
\hline
\end{tabular}

aValues are means of 3 replicates 
52

Tab. 7. Effect of pepper seedling soaking in antioxidant solutions on area under root rot/wilt progress curve during 2007-2008 and 2008-2009 growing seasons under field condition at New Valley, Egypt

\begin{tabular}{cccccc}
\hline \multirow{2}{*}{ Treatments } & \multirow{2}{*}{ Con. $(\mathrm{ppm})$} & \multicolumn{4}{c}{ Area under root rot/wilt progress carve at season } \\
\cline { 3 - 6 } & & Season 2007-2008 & \% Protection & Season 2008-2009 & \% Protection \\
\hline \multirow{3}{*}{ Coumaric acid } & 100 & $815.2^{\mathrm{a}}$ & 43.80 & 951.4 & 38.44 \\
& 200 & 524.3 & 63.86 & 697.2 & 54.89 \\
\hline \multirow{3}{*}{ Citric acid } & Mean & 669.75 & 53.83 & 824.3 & 46.66 \\
& 100 & 934.2 & 35.60 & 1025.4 & 33.65 \\
& 200 & 747.0 & 48.50 & 829.4 & 46.33 \\
\hline \multirow{3}{*}{ Propylgalate } & Mean & 840.6 & 42.05 & 927.4 & 39.99 \\
& 100 & 437.9 & 69.81 & 481.5 & 68.85 \\
\hline \multirow{3}{*}{ Salicylic acid } & 200 & 351.2 & 75.79 & 368.0 & 76.19 \\
& Mean & 394.55 & 72.80 & 424.75 & 72.52 \\
\hline
\end{tabular}

LSD at 0.05 for: Treatments $(A)=52.551$; Concentrations $(B)={ }^{* *}$; Seasons $(C)={ }^{* *}$; Interactions $(A x B x C)=97.222 ;$ "Values are means of 3 replicates

Tab. 8. Effect of soil drenching with antioxidant solutions on area under root rot/wilt progress curve during 2007-2008 and 20082009 growing seasons under field conditions at New Valley, Egypt

\begin{tabular}{cccccc}
\hline \multirow{2}{*}{ Treatments } & Con. $(\mathrm{ppm})$ & \multicolumn{4}{c}{ Area under root rot/wilt progress carve at season } \\
\cline { 3 - 6 } & & Season 2007-2008 & \% Protection & Season 2008-2009 & \% Protection \\
\hline \multirow{3}{*}{ Coumaric acid } & 100 & 525.4 & 63.78 & 615.2 & 60.19 \\
& 200 & 368.2 & 74.62 & 525.7 & 65.99 \\
& Mean & 446.8 & 69.20 & 570.45 & 63.09 \\
\hline \multirow{3}{*}{ Citric acid } & 100 & 835.0 & 42.44 & 991.3 & 35.86 \\
& 200 & 615.4 & 57.58 & 608.4 & 60.63 \\
\hline \multirow{3}{*}{ Propylgalate } & Mean & 725.2 & 50.01 & 799.85 & 48.25 \\
& 100 & 395.8 & 72.71 & 425.8 & 72.45 \\
\hline \multirow{2}{*}{ Salicylic acid } & 200 & 315.4 & 78.26 & 345.2 & 77.665 \\
& Mean & 355.6 & 75.49 & 385.5 & 75.06 \\
\hline
\end{tabular}

LSD at 0.05 for: Treatments $(A)=58.321$; Concentrations $(B)={ }^{* *}$; Seasons $(C)={ }^{* *}$; Interactions $(\mathrm{AxBxC})=102.564 ;{ }^{2}$ Values are means of 3 replicates

with 1450.6 in control and 991.3 and 608.4 compared to 1545.5 in control.

\section{The effect of antioxidants on pepper vigor and yield under} field conditions:

Seedling soaking and/or soil drench with any of these antioxidants were submitted to various growth parameters i.e. plant height, branch number, pod number/plant, and pod yield/plant. The data in Tab. 9 show that seedlings soaking in antioxidants offer interesting results as they markedly enhanced the physiological activities of these plants especially at high concentrations (200 ppm). Propylgalate achieved the highest increase in all the mentioned parameters over the other entire three antioxidants ions durring both seasons. The average plant length of untreated seedling was 34.44 and $36.1 \mathrm{~cm} / \mathrm{plant}$ in control, it recorded 65.44 and $61.40 \mathrm{~cm} /$ plant in PG treatment at 200 ppm in both seasons, respectively. The number of branches was 7.84 and 7.90 recorded in PG at 200 ppm compared to 5.07 and 5.00 branches/plant in control.

Soil drenching with antioxidants significantly increase all parameters compared to control (Tab. 10). Soil drenching with PG gave the highest results in all parameters while it recorded 69.27 and $68.90 \mathrm{~cm} /$ plant, 7.84 and 7.24 branch/plant, 30.60 and $33.40 \mathrm{pod} / \mathrm{plant}$ and 437.92 and $474.31 \mathrm{gm} /$ plant compared to 34.44 and $36.10 \mathrm{~cm} /$ plant, 5.07 and $5.0 \mathrm{branch} / \mathrm{plant}, 15.05$ and $16.90 \mathrm{pod} / \mathrm{plant}$, 248.52 and $308.74 \mathrm{gm} /$ plant in control in both seasons, respectively. On the other hand, salicylic acid came next PG in both applied methods (seedling soaking or soil drench). However, citric acid came at the end compared with the other treatments. 
Tab. 9. Effect of antioxidant solutions used as seedling soaking on pepper vigor plants (cv 'Anaheim-M') and pod yield/plant under field condition in season 2007-2008 and 2008-2009

\begin{tabular}{|c|c|c|c|c|c|c|c|c|c|}
\hline \multirow{2}{*}{ Treatments } & \multirow{2}{*}{$\begin{array}{l}\text { Con. } \\
\text { (ppm) }\end{array}$} & \multicolumn{2}{|c|}{ Plant height $(\mathrm{cm})$} & \multicolumn{2}{|c|}{ No. of branch/plant } & \multicolumn{2}{|c|}{ No. of pod/plant } & \multicolumn{2}{|c|}{ Pod yield $(\mathrm{gm}) /$ plant } \\
\hline & & $2007-2008$ & 20082009 & $2007-2008$ & $2008-2009$ & $2007-2008$ & $2008-2009$ & $2007-2008$ & $2008-2009$ \\
\hline \multirow{3}{*}{$\begin{array}{l}\text { Coumaric } \\
\text { acid }\end{array}$} & 100 & $35.67^{a}$ & 36.42 & 5.27 & 5.15 & 17.24 & 17.30 & 341.11 & 352.51 \\
\hline & 200 & 38.48 & 38.83 & 5.54 & 5.50 & 21.02 & 20.80 & 394.10 & 412.60 \\
\hline & Mean & 37.08 & 37.63 & 5.41 & 5.33 & 19.14 & 19.05 & 367.64 & 382.56 \\
\hline \multirow{3}{*}{ Citric acid } & 100 & 43.59 & 40.2 & 6.87 & 6.74 & 21.16 & 23.20 & 386.96 & 369.20 \\
\hline & 200 & 44.90 & 45.84 & 7.43 & 7.20 & 22.76 & 24.30 & 427.84 & 418.20 \\
\hline & Mean & 44.25 & 43.02 & 7.15 & 6.97 & 21.96 & 23.75 & 407.40 & 393.70 \\
\hline \multirow{3}{*}{ Propylgalate } & 100 & 48.58 & 49.81 & 6.99 & 7.32 & 21.90 & 25.40 & 429.66 & 455.21 \\
\hline & 200 & 65.44 & 61.40 & 7.84 & 7.90 & 29.74 & 32.60 & 465.50 & 486.25 \\
\hline & Mean & 57.01 & 55.61 & 7.42 & 7.61 & 25.82 & 29.00 & 447.58 & 470.73 \\
\hline \multirow{3}{*}{ Salicylic acid } & 100 & 42.23 & 46.35 & 6.17 & 6.22 & 20.20 & 20.42 & 351.40 & 386.20 \\
\hline & 200 & 56.67 & 53.20 & 6.77 & 6.80 & 28.52 & 28.62 & 463.96 & 439.17 \\
\hline & Mean & 49.45 & 49.78 & 6.47 & 6.51 & 24.36 & 24.52 & 407.68 & 412.69 \\
\hline \multicolumn{2}{|c|}{ Control } & 34.44 & 36.1 & 5.07 & 5.00 & 15.05 & 16.90 & 248.52 & 308.74 \\
\hline
\end{tabular}

\begin{tabular}{lllll}
\hline LSD at 0.05 for & Plant height & No. of branch/plant & No. of pod/plant & Pod yield $(\mathrm{gm}) /$ plant \\
\hline Treatments $(\mathrm{A})=$ & 2.574 & 0.232 & 0.235 & 16.937 \\
Concentrations $(\mathrm{B})=$ & $* *$ & $* *$ & $* *$ & $* *$ \\
Seasons $(\mathrm{C})=$ & $\mathrm{ns}$ & $\mathrm{ns}$ & $* *$ & $* *$ \\
Interactions $(\mathrm{AxBxC})=$ & $\mathrm{ns}$ & 0.409 & $\mathrm{~ns}$ & 34.208 \\
\hline avalues are means of 3 replicates & & &
\end{tabular}

Tab. 10. Effect of antioxidant solutions used as soil drenching on pepper vigor plants (cv 'Anaheim-M') and yield/plant under field condition in season 2007-2008 and 2008-2009

\begin{tabular}{|c|c|c|c|c|c|c|c|c|c|}
\hline \multirow[b]{2}{*}{ Treatments } & \multirow{2}{*}{$\begin{array}{l}\text { Con. } \\
\text { (ppm) }\end{array}$} & \multicolumn{2}{|c|}{ Plant height $(\mathrm{cm})$} & \multicolumn{2}{|c|}{ No. of branch/plant } & \multicolumn{2}{|c|}{ No. of pod/plant } & \multicolumn{2}{|c|}{ Pod yield $(\mathrm{gm}) /$ plant } \\
\hline & & $2007-2008$ & $\begin{array}{c}2008- \\
2009\end{array}$ & $\begin{array}{l}2007- \\
2008\end{array}$ & $2008-2009$ & $\begin{array}{c}2007- \\
2008\end{array}$ & $\begin{array}{c}2008- \\
2009\end{array}$ & $2007-2008$ & 2008-2009 \\
\hline \multirow{3}{*}{ Coumaric acid } & 100 & 38.55 & 36.20 & 5.27 & 5.20 & 17.10 & 17.40 & 345.31 & 362.40 \\
\hline & 200 & 39.26 & 42.80 & 5.54 & 5.31 & 20.86 & 21.60 & 408.52 & 421.50 \\
\hline & Mean & 38.91 & 39.50 & 5.41 & 5.26 & 18.98 & 19.50 & 376.95 & 391.95 \\
\hline \multirow{3}{*}{ Citric acid } & 100 & 46.71 & 41.54 & 6.87 & 6.80 & 18.62 & 20.10 & 330.61 & 364.10 \\
\hline & 200 & 51.19 & 49.30 & 7.43 & 6.60 & 19.10 & 21.70 & 403.06 & 409.51 \\
\hline & Mean & 48.95 & 45.42 & 7.15 & 6.70 & 18.86 & 20.90 & 366.87 & 386.81 \\
\hline \multirow{3}{*}{ Propylgalate } & 100 & 46.13 & 50.31 & 6.99 & 7.20 & 23.42 & 28.40 & 401.87 & 454.80 \\
\hline & 200 & 69.27 & 68.90 & 7.84 & 7.24 & 30.60 & 33.40 & 437.92 & 474.31 \\
\hline & Mean & 57.70 & 59.61 & 7.42 & 7.22 & 27.0 & 30.90 & 419.93 & 464.56 \\
\hline \multirow{3}{*}{ Salicylic acid } & 100 & 43.44 & 48.23 & 6.17 & 5.60 & 22.84 & 24.30 & 337.40 & 378.20 \\
\hline & 200 & 59.38 & 57.40 & 6.77 & 6.48 & 27.96 & 26.80 & 436.80 & 429.82 \\
\hline & Mean & 51.41 & 52.82 & 6.47 & 6.04 & 24.40 & 25.55 & 387.10 & 404.01 \\
\hline Contr & & 34.44 & 36.1 & 5.07 & 5.00 & 15.05 & 16.90 & 248.52 & 308.74 \\
\hline
\end{tabular}

\begin{tabular}{|c|c|c|c|c|}
\hline LSD at 0.05 for: & Plant height & No. of branch/plant & No. of pod/plant & Pod yield $(\mathrm{gm}) /$ plant \\
\hline Treatments $(\mathrm{A})=$ & 2.574 & 0.232 & 0.235 & 16.937 \\
\hline Concentrations $(\mathrm{B})=$ & ** & ** & ** & $* *$ \\
\hline Seasons $(C)=$ & ** & ns & * & ** \\
\hline Interactions $(\mathrm{AxBxC})=$ & ns & 0.449 & ns & 34.208 \\
\hline
\end{tabular}

aValues are means of 3 replicates 
54

\section{Discussion}

Pepper plants are subject to infection with many diseases (Lamb et al., 1999; Utkhede and Mathur, 2005 and Demirci and Dolar, 2006), among which the soil-borne diseases are the most important. Many fungi i.e Fusarium, Macrophomina, Rhizoctonia, Pythium, Verticilium and Sclerotinia .causing damping-off, root rot and wilt diseases are commonly encountered in the greenhouse, nurseries and fields (Lu et al., 1984; Fletcher, 1994; Soner Soylu et al., 2005 and Goicoechea, 2006).

Results of the present study showed that fungi isolated from naturally rotted roots and wilt foliage of pepper plants collected from four locations in New Valley Governorate, Egypt (Gharga, Farafrah, Dakhla and Baris), represented 2 species, belonging to Fusarium genus ( $F$. solani and $F$. oxysporum). Fusarium oxysporum isolate PF4 was highly pathogenic towards pepper plant caused $87 \%$ disease severity followed by $F$. solani isolate FP2 which caused $82 \%$ disease severity. Data are in accordance with those reported by Abada (1994), Mushtaq and Hashmi (1997), Sahi and Khalid (2007).

Results indicated that all tested antioxidants reduced damping-off, root rot/wilt and the area under root rot/ wilt progress curve caused by artificial infection with the tested fungi, when applied any application methods (seed soaking, seedling soaking and/or soil drenching).

Generally, the pest control was the tested solutions which was applied as soil drenching with high concentration (200 ppm) for the tested antioxidants. Propylgalate was better than the other antioxidants to reduced damping-off, root rot/wilt and the area under root rot/wilt progress curve caused by any tested fungi. Similar results were reported by Galal and Abdou (1996) who found that application of salicylic or ascorbic acid as a soil drenching was better than foliar application to control fusarial diseases of cowpea. Also, Mostafa (2006) reported that soaking cumin seeds or soil drenching with antioxidant solutions (salicylic, ascorbic, coumaric, benzoic acids, and propylgalate) before planting resulted in resistant cumin seedlings against infection with the Fusarium oxysporum cumini and Acremonium egyptiacum. Abdel-Monaim (2008) showed that soaking lupine seeds in antioxidant solutions (reduced the damping-off and root rot diseases caused by Fusarium solani and Macrophomina phaseolina. In vitro all antioxidants show less effect on dry weight. Propylgalate had the highest effect on spore formation especially highly concentration (200 ppm).

The antioxidants mode of action was reported in many host-pathogen interactions i.e. many oxidative enzymes such as peroxidase, catalase, ascorbate oxidase and polyphenol oxidase were detected as a result of infection with many pathogens (Clark et al., 2002) or as a result of treatments with various antioxidants (Takahama and Oniki, 1994, El-Khallal, 2007b and Abdel-Monaim, 2008). Moreover, Lyon and McGill (1989) reported that the phenolic acids benzoic, ferulic, coumaric and protocatechoic acid inhibit in-vitro activity of polygalacturonase and polygalacturonic acid lyase from Erwinia carotovora. Chen et al., (1993) reported that SA binds to, or inhibits catalase.

Also in the present study shows that all tested antioxidants reduced the area of the root rot/wilt under field conditions and increased the plant vigor and pod yield per plant in both seasons. The increase in pepper yield may be due to the role of antioxidants in stimulation of physiological processes which reflect the improving vegetative growth that followed by active translocation of the photoassimilation. In this respect, antioxidants might be right being regulating plant growth by increasing enzyme activity as $\alpha$-amylase and nitrate reductase, which accelerate the sugar translocation from the leaves to developing fruit (Sharma et al., 1986). In addition, application of SA inhibits ethylene production leading to an increase in fruit number and consequently increases fruit yield per plant (Leslie and Romani, 1986). Abdel-Monaim (2008) found that lupine seed soaking in antioxidant solutions increases of chlorophyll and carotenoids content in leaves and this reflects the health condition of the plant.

\section{References}

Abada, K. A. (1994). Fungi associated with root rot of pepper and some factors affecting disease incidence. $7^{\text {th }}$ Congress of Phytopathology, Giza. 220-226.

Abdel-Monaim, M. F. (2008). Pathological studies of foliar and root diseases of lupine with special reference to induced resistance. Ph. D. Thesis, Fac. Agric., Minia University.

Agrios, G. N. (1988). Plant Pathology, 3rd. ed. Academic Press.

Barnett, H. L. and B. B. Hunter (1972). Illustrated genera of imperfect fungi. Burgess Pub. C.C., Minnesota.

Chen, Z., H. Silva and D. F. Klessig (1993). Active oxygen species in the induction of plant systemic acquired resistance by salicylic acid. Science 262:1883-1885.

Clark, F. S., P. L. Guy, D. J. Burritt and P. E. Jameson (2002). Changes in the activities of antioxidant enzymes in response to virus infection and hormone treatment. Physiol. Plantarum 114:157-164.

Demirci, F. and F. S. Dolar (2006). Effects of some plant materials on phytophthora blight (Phytophthora capsici Leon.) of pepper. Turk. J. Agric. 247-252.

Elad, Y. (1992). The use of antioxidants (free radical scavengers) to control grey mould (Botrytis cinerea) and white mould (Sclerotinia sclerotiorum) in various crops. Plant Pathology 41:417-426.

El-Khallal, M. S. (2007b). Induction and modulation of resistance in tomato plants against Fusarium wilt disease by bioagent fungi ( $A$. mycorrhiza) and/or hormonal elicitors (jasmonic acid and salicylic acid): 2-Changes in the antioxidant enzymes, phenolic compounds and pathogen related-proteins. Austr. J. of Basic and App. Sci. 1(4):717- 
732.

Elwakil, M. A. (2003). Use of antioxidant hydroquinone in the control of seed-borne fungi of peanut with special reference to the production of good quality seed. Pakistan J. of Plant Pathology 2(2):75-79.

Fletcher, J. T. (1994). Fusarium stem and fruit rot of sweat peppers in the glasshouse. Plant Pathology 43:225-227.

Galal, A.A. and S. El-Abdou (1996). Antioxidants for the control of Fusarial diseases in cowpea. Egypt J. Phytopathol. 24:112.

Galal, A. Hussien, A. Nour El-Hoda, M. R. Abdel-Latif and A. Armanious Hanaa (2001). Control of cotton root rot and wilt by ascorbic acid, propylgalate, thiourea and Benlate. Proc. of Safe Alternatives of pesticides for pest Management.

Gilman, J. C. (1957). A manual of soil fungi: Iowa. State. Univ.

Goicoechea, N. (2006). Verticillium-induced wilt in pepper: Physiological disorders and perspectives for controlling the disease. Plant Pathology J. 5(2):258-265.

Gomez, K. A. and A. A. Gomez (1984). Statistical procedures for Agricultural Research. Interscience Publication. New York.

Hassan, M. E. M., Abdel-Rahman, S. Saieda, I. H. El-Abbasi and M. S. Mikhail (2006). Inducing resistance against faba bean chocolate spot disease. Egypt. J. Phytopathol. 34(1):69-79.

Lamb, E. M., R. M. Sonoda, E. F. Oxman and J. E. Curry (1999). Identification and incidence of Fusarium stem rot in greenhouse peppers in south Florida. Proc. Fla. State Hort. Soc. 112:308-309.

Leslie, C. A. and R. J. Romani (1986). Salicylic acid a new inhibitor of ethylene biosynthesis. Plant Cell Rep. 5:144146.

Liu, L., J. W. Kloepper and S. Tuzun (1995). Introduction of systemic resistance in cucumber against Fusarium wilt by plant growth-promoting rhizobacteria. Phytopathology 85:695-698.

Lu, J. Y., C. F. Yu and L. H. Ju (1984). Studies on differentiation of the virulence of Verticillium dabliae on pepper. Acta Phytopathologia Scientia 14(4):213-218.

Lyon, D. G. and G. M. McGill (1989). Inhibition of polygalacturonase and polygalacturonic acid lyase from Erwinia canuonna subsp. carotovora by phenolics in vitro. Potato Research 32:267-274.

Mahmoud, E., Y. Shokry, Y. M. Samia and N. Hussin Zeinab (2006). Induction of resistance in peanut plants against root rot diseases under greenhouse conditions by some chemical inducers. J. Agric. Sci. Mansoura Univ. 31(6):3511-3524.
Mohamed, M., A., G. W. Shousha, M. E. Mahdy, A. M. Ghazy and M. M. Manal (2007). Biochemical alterations induced in tomato in response to Fusarium oxysporum infection: purification and characterization of an acidic $\alpha-1,3$ glucanase. Res. J. of Agric. and Biol. Sci. 3(6): 939-949.

Mostafa, W. E. B. (2006). Studies on some cumin diseases. M. Sc. Thesis, Fac. Agric., Minia Univ.

Mushtaq, M. and M. H. Hashmi (1997). Fungi associated with wilt disease of Capsicum in Sindh, Pakistan. Pak. J. Bot. 29(2):217-222.

Nelson, E. P., A. T. Toussoun and O. F. W. Marasas (1983). Fusarium species. An Illustrated Manual for Identification. The Pennsylvania state Univ. Press.

Nighat-Sarwar, M. C. Hayat-Zayaid and H. Ikramul (2005). Induction of systemic resistance in chickpea against Fusarium wilt by seed treatment with salicylic acid and Bion. Pakistan. J. Bot. 37(4):989-995.

Pandy, H. N., T. C. M. Menon and M. V. Rao (1989). Simple formula for calculating area under disease progress curve. Rachis 8 (2):38-39.

Rajkumar, M., K. J. Lee and H. Freitas (2008). Effects of chitin and salicylic acid on biological control activity of Pseudomonas spp. against daping-off of pepper. South African J. of Botany 74:268-273.

Sahi, I. Y. and A. N. Khalid (2007). In vitro biological control of Fusarium oxysporum causing wilt in Capsicum annuum. Mycopath 5(2):85-88.

Sharma, S., S. Sharma and V. K. Rau (1986). Reversal by phoenolic compounds of absissic acid-induced inhibition of in vitro activity of $\alpha$ - amylase from seeds of Triticum aestivum L. New Phytol. 103:293-297.

Soner, Soylu, Mine Soylu, Sener Kurt and O. K. Ekici (2005). Antagonistic potentials of rhizosphere associated bacterial isolates against soil-borne diseases of tomato and pepper caused by Sclerotinia sclerotiorum and Rhizoctonia solani. Pakistan J. of Biol. Sci. 8(1):43-48.

Takahama, U. and T. Oniki (1994). Effects of ascorbate on the oxidation of derivatives of hydroxycinnamic acid and the mechanism of oxidantion of sinapic acid by cell wall- bond peroxidases. Plant Cell Physiol. 35:593-600.

Tzeng, D. D. and J. E. De Vay (1989). Biocidal activity of mixture of methionine and riboflavin against plant pathogenic fungi and bacteria and possible modes of action. Mycologia 81: 404-412.

Utkhede, R. S. and S. Mathur (2005). Biological and chemical control of fruit rot in greenhouse sweet peppers (Capsicum annum L.) caused by Fusarium subglutinans. J. of Biol. Sci. 5(5):610-615. 